FORUM 


\title{
Wal-Mart, American consumer citizenship, and the 2008 recession
}

\author{
Jane Collins
}

\begin{abstract}
This article explores dominant ideological framings of the economic crisis that began in 2008, by examining shifting meanings of consumer citizenship in the US. The consumer citizen was a central figure in Keynesian ideology-one that encapsulated important assumptions about the proper relationship between production and consumption and the appropriate arenas for citizen engagement with the economy. Taking Wal-Mart as a case-study example, the article analyzes the way that corporate actors have flattened and reconfigured the concept of consumer citizenship in the US-promoting the "consumer" over the "citizen" and the "worker," which had previously been important aspects of the concept-and have replaced Keynesian-era conversations about the proper balance between production and consumption with a rhetoric of choice between low prices and high wages.
\end{abstract}

Keywords: consumer citizenship, Fordism, Keynesianism, labor, Wal-Mart

The late twentieth century was a time of global economic change, as corporations and their allies worked to dismantle the Keynesian frameworks that had been designed to stabilize employment and balance production and consumption within the economy. This dismantling was accompanied by struggle over such fundamental issues as the role of the state in the economy, the responsibilities of employers to workers, and the meaning of citizenship. While academics and policymakers have debated these changes at length, I would like to focus on recent shifts in the meaning and practice of consumer citizenship in the US, as reflected in the corporate practices of Wal-Mart, to suggest a new perspective. As Lizabeth Cohen (2003) and others have shown, consumer citizenship in the US encapsulates a dense set of relationships among citizens, the state, and employers, as well as a complex set of ideas about "the market." Examining the fate of the consumer citizen thus provides a window into the reconfiguration of these relationships and ideas in key periods.

One corporate actor has played a greater role than any other in shaping consumer citizenship in the US since the 1980s-the giant retailer Wal-Mart. Wal-Mart is the leading retailer in the US, where it serves 20 percent of demand in the sector. With over 2 million workers worldwide (1.4 million in the US), it is moreover the 
largest employer not just in the US but in the world. Through its emphasis on low prices, Wal-Mart has arguably elevated the importance of the consumer citizen. The firm's retailing strategy and advertising campaigns suggest that market consumption is the most important way that a citizen can pursue his or her economic interests. It offers the strategy of seeking the lowest price as an alternative route to prosperity and inclusion-a "win-win" scenario that entails less conflict than seeking a union contract or a living wage. At the same time, through its efforts to keep down pay and benefits and to erode worker rights, Wal-Mart has undermined the capacity of low-wage workers in the US to act effectively as consumers.

The recession that began in 2008 deepened this contradiction, as sharply declining consumer demand in the US led to the unraveling of Wal-Mart's "Always Low Price" strategy. Exploring this moment in the firm's history reveals not only the fragility, and perhaps hypocrisy, of its commitment to economic empowerment through cheap goods. It also makes visible the damage done by the firm's rhetorical and material reshaping of the terrain of the consumer citizen. The story told here is historically and geographically specific, reflecting the unique version of consumer citizenship that arose in the US context and the particular retailing strategies and labor practices that Wal-Mart uses in that country. ${ }^{1}$ But as a variation on a broader set of neoliberal corporate practices that undermine worker rights by appealing to the need for low pricing and that reinterpret citizenship as market participation, the insights it generates are potentially of great relevance to a wider range of contexts.

\section{The American consumer citizen from Fordism to neoliberalism}

A long stream of radical scholarship focuses on mass consumption, from Thorstein Veblen's Theory of the leisure class (1899) to Sharon Zukin's Point of purchase (2004). While much of it has decried consumerism as tied to inequality, individual greed, eroded social norms and values, and declining social responsibility, a certain strand has explored the social benefits and even the liberating potential of some kinds of consumption. Key among this work is Lizabeth Cohen's account of the rise of the idea of the consumer citizen in the US in the mid-twentieth century. In her 2003 book A consumer's republic, Cohen charts the emergence of two versions of consumer citizenship that competed for ascendancy in the public sphere during this period. The first was the vigilant "consumer citizen," who prodded government to protect the rights, safety, and fair treatment of purchasers (and also, at times, of the workers who produced goods). The second was the "purchaser consumer," whose retail prowess was the motor of the economy- "individuals who contributed to society more by exercising purchasing power than by asserting themselves politically" (Cohen 2003:19).

Drawing on forms of public participation with roots in the Progressive Era, ${ }^{2}$ consumer citizenship in the first sense found expression in grassroots struggles for pure food and drugs, antitrust laws, fair prices, minimum wages, and just labor standards. It had roots in the early twentieth-century National Consumers' League, whose "ethical consumption" initiatives sought to pressure employers and the government to improve wages and working conditions, as well as to insure wholesome and sanitary products. Unions also promoted this sort of ethical consumption through "union label" campaigns and boycotts and exposés of unscrupulous employers. As these campaigns and associated "rights" found expression in the programs and policies of the New Deal, Cohen argues that consumers arose as a "self-conscious, identifiable interest group on a par with labor and business whose well-being required attention for American capitalism and democracy to prosper" (Cohen 2003: 23).

Consumer citizenship in the second sense"the purchaser consumer"-referred to the role consumers played in creating demand within the economy as a whole. Cohen cites the example of a public-relations film produced by Gen- 
eral Motors in 1937 that portrayed workers picking up their paychecks and then, accompanied by wives and children (and a triumphal soundtrack), spending them in downtown stores on bicycles, furniture, and household appliances. "Because America has a ready purse and gives eager acceptance to what the men of motors have built," the film proclaims, the United States will enjoy "a prosperity greater than history has ever known" (From dawn to sunset, in Cohen 2003: 20). Economic regulation theorists, referencing Antonio Gramsci (cf. Gramsci [1937] 1971), called this virtuous relationship between production and consumption Fordism-in recognition of the Ford Motor Company's famous consumption-boosting innovation: the five-dollar-a-day wage .

Insiders in Franklin Delano Roosevelt's administration debated the degree to which efforts to recover from the Great Depression should put the worker or the consumer at the center. Keynesianism offered a strong argument for deficit spending to fuel consumer demand, with advocates declaring that "the future of this nation is built upon spending, not saving" (Ernest Erber, cited in Cohen 2003: 55). Keynes and his followers argued that fostering a wide distribution of purchasing power also enhanced economic equality (ibid.). Franklin Roosevelt summed up the case: "If the average citizen is guaranteed equal opportunity in the polling place, he must have equal opportunity in the marketplace" (cited ibid.: 56). US economist John Kenneth Galbraith ([1952] 1993) argued later that these ideas institutionalized for the first time the concept of the consumer as a "countervailing power" to balance more powerful interests such as big business. While the New Deal's critics have correctly emphasized that it did not extend benefits equally to women or people of color, and that its policies sometimes marginalized more progressive projects, its vision of government's role in guiding and regulating the economy opened new spaces for social mobilization, including around the identity of the consumer.

During World War II, the vigilant American consumer citizen participated in rationing programs, deferred spending, monitored stores for adherence to price controls, and planted Victory Gardens. But at war's end, Cohen argues that the consumer citizen and purchaser consumer merged into a singular "purchaser as citizen," whose house in the suburbs and modern appliances fueled the nation's economic growth, even as they bolstered existing relations of family, race, and class. In the wake of World War II, both corporations and government praised the good consumer as a patriotic citizen, one who fostered the recovery of the nation's economy. The Nixon-Khrushchev "kitchen debates" of the 1950s featured the American housewife as the appliance-rich author and beneficiary of the prosperity that capitalist free markets could bring. Media scholar Sheila Webb summarizes the moment: "In the postwar years, as mass production expanded, corporations grew and living standards rose. Advertising and communications networks worked to sustain the rate of consumption, and public opinion polling began to assess not only political views but consumption patterns." Major media outlets, such as Life magazine, "strove to create a community of citizens who, with the proper training and knowledge, could thrive in this new society" (Webb 2006: 3). Cohen calls this convergence of the two earlier modes of consumer citizenship an "alluring compromise," which promised that the pursuit of individual satisfaction could serve society as a whole.

By the 1970s, Keynesianism had fallen out of favor in the US, but the concept of the "purchaser as citizen" had not. In the 1970s and 1980s, as more women moved into the US workforce, the media portrayed them as learning to balance their traditional role as consumer with a new one as wage earner. Paraphrasing the song "I'm a Woman," ads proclaimed women's new ability "to bring home the bacon and fry it up in the pan." The purchaser citizen rode the credit boom of the 1990s, and in the immediate aftermath of the attacks on the World Trade Center in September 2001 was called out by President George Bush to demonstrate patriotism by spending. Cohen notes that the pervasive neoliberalism of the late twentieth century reworked consumer citizenship once again, as it 
recast activities of government and political participation in market terms. She calls this newest configuration the "consumer/citizen/taxpayer/voter"-highlighting the way neoliberal discourse encourages citizens to view taxes, voting, and other political activities as market transactions and to judge them by "how well-served they feel personally" (Cohen 2003: 9).

Cohen's account might be criticized for flattening a multitude of dimensions of American working-class and middle-class life at mid-century-its labor activism, gender relationships, and community ties. To some extent, this is to be expected, since the object of her study is the emergence of a paradigm of civic participation that itself relies on such a flattening-that creates a mode of citizenship consistent with a society mediated largely by market relationships. Nevertheless, in tracing the emergence of this paradigm, she consistently downplays what it displaces-the modes of civic and political engagement that are lost as a result. Focusing on the case of Wal-Mart as a key actor highlights the loss of these alternative modes of citizenship, as well as the active corporate labor required to undermine and replace them.

\section{Wal-Mart reconfigures the consumer citizen}

For anyone studying low-wage work, Wal-Mart is in one sense a metonym-a part of the consumer economy that can stand in for the US economy as a whole. But in another sense, because of its size and the role it plays in setting the parameters for competition in the retail sector-and the low-wage labor market more generally-it merits study in its own right. Sociologists Gary Gereffi and Michelle Christian call the firm "a driver and organizer of global processes" (2009: 574). Gereffi claims that "whatever Wal-Mart does in terms of the labor market, all other businesses have to follow.... Wal-Mart is really determining the direction in which the US labor market is moving" (Gereffi 2004). Historian Nelson Lichtenstein concurs: "Wal-Mart is setting a new standard that other firms have to follow if they hope to compete.... It is setting standards for the nation as a whole. It's almost legislating social policy, not in terms of votes and lobbying, but when it does something, it's so large, it's so influential, others follow it" (2004).

As the story of Wal-Mart's rise is told, it is clear that it not only represented, but drove, a whole new paradigm of consumerism in the US-one focused on the car, one-stop shopping, and price as the main dimension of competition (Fishman 2006, Lichtenstein 2006, 2009, Moreton 2009, Strasser 1989, Zukin 2004). Bolstering that paradigm was Wal-Mart's folksy, southern "hometown" self-presentation, which as these authors suggest was laden with messages about how one should labor, act in relation to state and market, and organize intimate relationships. And behind the scenes of the firm's success lay the latest in supply-chain management technologies, the world's biggest global sourcing network, and astonishingly low manufacturing wages.

Wal-Mart has habitually justified its stingy wages in the US and abroad by reference to an attenuated notion of the "purchaser as citizen." Like the postwar version that Cohen refers to, it encourages people to think of their interests primarily in relation to consumption through the market, and to see that approach as responsible and patriotic. In contrast, however, it explicitly silences other assertions of rights or interests as workers, community members, or citizens. The firm organizes this argument about the appropriate way to pursue one's interests around the concept of low prices and how they serve society.

The company's corporate Web site provides an illustration of this logic. It declares "we know that price matters to our consumers, whether they live in the United States, the United Kingdom, Argentina or Japan." It explains that saving money is connected to living better because it can help the consumer "afford something a little extra." It offers the examples of a grandmother who can buy her grandchildren a special gift because she saved money on her prescriptions, or a young couple who can use the 
savings to pay for a new home (Wal-Mart Corporate 2011).

To support these rhetorical claims, in 2005 and 2007 Wal-Mart paid economists at a consulting firm to come up with an estimate of the amount it had saved US consumers. The firm, Global Insight, suggested a cumulative figure of 287 billion USD by 2006, and Wal-Mart widely disseminated this information on its Web site, in news releases, in corporate interviews, and in circulars with titles like "Wal-Mart's effect on grocery prices fact sheet" and "Wal-Mart saves Americans money fact sheet." Based on these studies, Wal-Mart's corporate officials argue that the firm saves working families an average of over 2300 USD per household per year, and lowers the grocery bills of families who shop there by 20 percent over competitors' prices. It claims that its low prices contributed to a 3.1 percent decline in consumer prices across the nation as a whole. Former CEO Lee Scott called this "a wage increase" for the working poor in America. While independent economists have challenged these estimates on all fronts-data used, assumptions made, soundness of econometric analysis, logic of argument (Bernstein and Bivens 2006) - the company continues to circulate the reports' conclusions. Its insistent rhetoric about low prices as a social benefit that trumps all others led one anticorporate activist to comment: "Every time we try to talk about quality of life, they bring up the price of underpants" (Greenwald 2005).

Critics of Wal-Mart have argued that it hurts US workers in two ways: by pushing other US retailers and the firm's own US suppliers out of business, thus destroying jobs, and by eroding conditions in the remaining jobs in the lowwage labor market. The claim that Wal-Mart drives out local businesses by undercutting them on price wherever it sets up a store has been well vetted. But Wal-Mart also places pressure on its US suppliers' factories, demanding supply-chain innovations, quality improvements, and price reductions. When these companies cannot afford to innovate or cannot continue to push their price points down, WalMart turns to offshore suppliers, leading firms that have relied heavily on its business to close (Gereffi 2004).

Wal-Mart also unleashes a race to the bottom in local labor markets in the US, by setting in motion competitive forces that are vicious rather than virtuous, in the sense that they are structured around cost-cutting rather than technological or labor-process improvements. When it moves into a community as a retailer, economists have shown that it depresses the prevailing wage rate, unleashing a vicious cycle in which profits, lower consumer prices, and poverty-level wages are intertwined (Dube and Jacobs 2004). Goetz and Swaminathan (2006) studied the relationship between Wal-Mart and county poverty rates. Controlling for other factors that could influence impoverishment, they found that counties with more Wal-Mart stores had higher rates of poverty than those with fewer or no Wal-Mart stores. They calculated that the opening of a new Wal-Mart store increases the average poverty rate in a county, and that an additional 20,000 US families were in poverty in 1999 as a result of Wal-Mart's presence in their communities. The mechanisms by which poverty is transmitted are primarily competitive-by offering jobs at a low wage, the company drives down competitors' wages, or at least keeps them from rising. But antiunion tactics and driving firms with unionized or higherpaid workforces out of business also play a role.

At mid-twentieth century, the conventional wisdom would have criticized such an approach as "killing the goose that lays the golden egg"that is, as eroding the buying power of the customer base. But a very different logic informs Wal-Mart's corporate strategy. Wal-Mart knows that the poor are its most important customers-it locates its stores near them, researches their habits and preferences, and targets them in advertising. Liza Featherstone quotes one of the women she interviewed for her research as saying, "They plant themselves right in the middle of Poorville" (Featherstone 2005). WalMart's corporate strategy-its discourse and practice-inverts the relationship between production and consumption that policymakers of the Keynesian era tried to protect and that the 
era's concept of citizenship embodied. A number of scholars have shown that Wal-Mart's low prices and its low wages are perversely relatedbound together in a way that inverts Henry Ford's bargain (Collins 2010, Featherstone 2004, Gereffi 2004). As Liza Featherstone says, "In a chilling reversal of Henry Ford's strategy ... to pay workers amply so they could buy Ford cars, Wal-Mart's stingy compensation policies contribute to an economy where workers can only afford to shop at Wal-Mart" (Featherstone 2004:219). In the words of Gary Gereffi, "WalMart is pushing wages down to a level where the people that work in Wal-Mart stores are going to be forced to buy in Wal-Mart stores, because they can't make enough money to buy goods elsewhere in the economy" (Gereffi 2004).

While Wal-Mart plays a material role in undermining wages and working conditions in the low-wage labor market, it is also important to notice what is forced out of the public conversation by the company's rhetoric of consumer economizing. While New Deal-era formulations of consumer citizenship saw purchasing as only one of the roles a citizen could play in the economy, and emphasized a virtuous connection between high wages and the ability to consume, in Wal-Mart's rhetoric the consumer role trumps all other aspects of citizenship, including the economic citizenship of the worker and the voice of the rights-bearing participant in the public sphere. In claiming that society gains more from lower prices than from fair wages, Wal-Mart implies that workers' hard-won rights and protections are rendered unnecessary by its pricing policies. Of course, unlike money in a paycheck that can be used for any purpose, the benefits of low prices can only be realized by shopping at Wal-Mart. This formulation does not consider the worker to be an autonomous being, who might choose to save rather than consume immediately, or to invest in a home, education, or health care rather than Wal-Mart's wares. The company's energetic and preemptive antiunion strategies speak to another aspect of citizenship it would rather not confront (see Featherstone 2005, Lichtenstein 2009).

By shifting the conversation from rights at work or rights in the public sphere to rights in the shopping aisle, Wal-Mart's discourse of low prices reworks the idea of the consumer citizen. Just as the purchaser as citizen left behind the idea of the citizen as a watchdog for unfair or unsafe practices, Wal-Mart's version leaves behind the idea of consuming to support the national economy. Despite its brief "Buy American" campaign in the 1980s, the firm has always been an aggressive importer, and its competitive strategy is based on perfecting ways to import cheaply and efficiently (Gereffi and Christian 2009: 577). Wal-Mart's consumer citizen exercises her citizenship through consuming, not in order to keep factories humming and employment rates low, but simply because that is the best way to pursue her own interests and those of her family. Wal-Mart's iconic shopper does not ask whether a toy contains lead or cadmium, or if the girls sewing her blue jeans (or the clerks selling them) are paid a living wage. She does not think about the effect that buying from WalMart will have on the small grocery store down the street, or whether her purchases will contribute to the health and strength of her local or national economy. She simply compares prices.

Following a path that Cohen describes in her book, Wal-Mart's version of the consumer citizen coincides with a neoliberal political rationality that portrays citizens as entrepreneurs of the self, all of whose relations, attachments, and endeavors are construed in market terms. Wendy Brown has argued that this attenuated version of consumer citizenship is a key component of what she calls "neoliberal de-democratization," and that it works through devaluing political autonomy and by transforming political problems into individual dilemmas with market solutions (Brown 2006). The collective power of grassroots consumer movements and the state-supported rights of workers are both rendered "superfluous" by this vision of the consumer citizen.

\section{Wal-Mart's consumer citizen in the economic crisis}

How did this revamped version of the consumer citizen, whose new image was fostered 
and groomed by Wal-Mart, fare during the recession that began in the US in 2008? Specifically, how did a consumer citizen whose well-being had been conflated with-and reduced to-access to low prices fare in a context of increased unemployment? In the early days of the recession, it should come as no surprise that Wal-Mart thrived. For all of the reasons just outlined, Wal-Mart is what has been called a "counter-cyclical firm"-one whose fate moves in the opposite direction to the overall economic cycle and whose profits rise when the economy is weakening. Other examples include fast-food firms like McDonald's and Burger King, some kinds of gardening and home-repair lines, craft stores, frozen yogurt, and most sadly, hand guns. As the Huffington Post put it, "Wal-Mart was in the sweet spot of the Great Recession. As shoppers traded down to cheaper stores, Wal-Mart gained market share" (2010). The New York Times declared the company "a winner amid the downturn" (2010a). Former Wal-Mart CEO Lee Scott put it bluntly: "I feel we are well positioned for an economic downturn. Our low prices and low-cost business model should give us an advantage over other retailers if things get more difficult for consumers" (CNN Money 2007). The company's sales in 2009, according to its own estimates, were up 7.2 percent over 2008, reaching 401 billion USD.

By the beginning of 2010, however, as continuing unemployment and underemployment took their toll, even Wal-Mart's low-priced merchandise was no longer a bargain that its poorest customers could afford. In 2009, 43.6 million people ( 1 in 6$)$ were living in poverty. The figure was 1 in 5 for children. Nearly 15 percent of families were living below the federal poverty line (Economic Policy Institute 2010). By 2010, Wal-Mart was struggling to hold on to its customers, as they turned to dollar stores and thrift shops for their needs or simply stopped buying all but the most essential items. Wal-Mart took a look at its data. "Spending patterns ... suggest that [our] customers have been hit particularly hard by the recession," its Chief Financial Officer said. "The low income consumer appears to be the last coming out." He noted that custom- ers' use of food stamps was up significantly, and that they were spending according to a "paycheck cycle"-making their largest purchases when their salaries first come in and cutting back as that money runs out (New York Times 2010b, 2010c). In an article entitled "Watching us save, one cart at a time," Newsweek noted that Wal-Mart managers had observed the following recession-related behaviors among their customers: more discarded items near cash registers, greater use of grocery lists, increased purchase of generics, fewer discretionary purchases, increased consumption of take-andbake pizzas (presumably substituting for more expensive pizza delivery), asking questions of pharmacists that might normally be part of a doctor's visit, more requests to hit the subtotal key when checking out, fewer purchases per trip, more shopping on payday (Newsweek 2009). A Wall Street Journal article hinted at the desperation that underlay this pattern:

"At midnight on the first of the month, a scene unfolds at many Wal-Mart Stores ... that underscores the deep financial strains that many lowincome American consumers still face. Parking lots come to life after 11 p.m. as customers start to stream into the stores, cramming their shopping carts full of milk, infant formula and other necessities.Then at midnight, when the government replenishes their electronic-benefit accounts with their monthly allotments of food stamps, nutritional grants for mothers with babies or other aid for needy families, they head for the registers. 'We're not starving or anything, but we come every month at 11:55, said Tyrel Fogle, 26 years old, early Friday morning as he loaded a cart with frozen food at a WalMart here on the northwestern edge of the nation's fourth largest city [Houston]. Mr. Fogle said he had just found work as a washer at a glass company after months of fruitless searching. 'We have enough to survive,' volunteered his pregnant girlfriend, Brittany Cummings, 21. 'But not much more."

The Journal concluded with a quote from Bill Simon, Wal-Mart's President and CEO: "If you really think about it, the only reason someone 
gets out there in the middle of the night and buys baby formula is that they need it, and they have been waiting for it" (Wall Street Journal 2010).

The mega-retailer's first response to its declining sales revenues was to cut prices, a strategy it avidly pursued from the beginning of the recession to June, 2010. After its shareholder meeting that month, when some stock analysts declared the company a "little bit lost in navigating the economic downturn," it began to reconsider its options (New York Times 2010c). Without much fanfare, the "Always Low Prices" firm began to resticker its goods. Unable to compete by undercutting its competitors, it began to raise prices. In August 2010, J. P. Morgan noted a near 6 percent increase in the average price of a market basket of groceries at WalMart. In October, the firm found that the price of the same basket had risen 2.7 percent in September; seven of its items were up 10 percent or more since August, and overall prices at the rollback retailer were at their highest level in 21 months (Reuters 2010, Time 2010). At the same time, Wal-Mart's Sam's Club stores announced 11,000 layoffs in 2010. And many Wal-Mart workers who received health insurance and benefits through state programs saw those benefits disappear as a result of state budget cuts.

These actions illustrate that Wal-Mart's version of the consumer citizen was not about citizenship at all. There is obviously no right to low prices that can be invoked at the checkout counter, no democratically agreed-upon criterion for what a fair price might be. It was in one sense a fabrication - a screen behind which real rights were being dismantled. Maintaining low prices became the justification for hourly starting wages of just over 7.00 USD, yielding between 12,000 USD and 14,000 USD a year for a full-time worker, far below the federal poverty line, and making the worker eligible for food stamps. It became the rationale for the fact that 46 percent of Wal-Mart workers' children are uninsured or on Medicaid. It was the reasoning that lay behind the lack of compliance with workers' compensation policies, labor laws, and antidiscrimination laws that led to litigation in courts around the nation (Bernstein and Bivens 2006, Featherstone 2004, Walmartwatch.com).

But in another sense, Wal-Mart's claims about its benefits to consumers did significant cultural and political work. As it wove together longstanding cultural themes of consumer citizenship with new ones from neoliberalism, WalMart convinced a sizeable section of the US public to engage in a national conversation about the "trade-off" between low prices and low wages. It convened seminars and commissioned studies on the topic. Its framing of the debate was adopted by independent scholars who tried to assess its impact (see, for example, Irwin and Clark 2006). Just as the firm's business model inverted Fordism, this conversation replaced Keynesian insights about the virtuous connection between production and consumption with a seemingly stark either/or choice: if you want low prices, wages must also be low. Calling this a "false choice," economist Jared Bernstein has argued that Wal-Mart could raise wages 13 percent-to the level of its key competitor Costco-without raising its prices, and still have higher profit margins than a main competitor (Bernstein and Bivens 2006). Wal-Mart doesn't encourage this kind of discussion about what constitutes a fair wage in its conferences or the media, and it need not negotiate such issues with its nonunion employees.

Rehabilitating a politically useful concept of consumer citizenship in the US therefore requires undoing a series of ideological tricks that are entailed in Wal-Mart's hijacking of the concept. It requires recovering the figure of the worker and linked notions of economic citizenship, fair wages, and just conditions of work. It requires dusting off the citizen-the rightsbearing participant in civil society, whose labor is protected in the US context by the National Labor Relations Act and the Equal Employment Opportunity Commission and who enjoys the right to engage in collective action on behalf of her interests. Wal-Mart's flattened version of the consumer citizen is not going to be able to shop her way out of economic crises like the one that began in 2008. But restoring a more robust notion of consumer citizenship may help lay the 
groundwork both for community-based labor movements, by tracing new arenas for citizen engagement with the economy, and for new forms of democratic governance in pursuit of a just and sustainable relationship between production and consumption.

Jane Collins is Evjue Bascom Professor of Community and Environmental Sociology and Gender and Women's Studies at the University of Wisconsin, Madison. She is the author of Threads: Gender, labor and power in the global apparel industry (University of Chicago, 2003), and recently coauthored, with Victoria Mayer, Both hands tied: Welfare reform and the race to the bottom in the low wage labor market (University of Chicago Press, 2010).

E-mail: jcollins@ssc.wisc.edu

\section{Notes}

1. As Tilly (2007) has pointed out, Wal-Mart's retailing, price, and labor-recruitment strategies vary markedly in different countries.

2. The Progressive Era in the United States was a period of social activism and reform that shaped politics at the local, state, and national levels from 1890-1920.

\section{References}

Bernstein, Jared, and Josh Bivens. 2006. The WalMart debate: A false choice between prices and wages. Washington: Economic Policy Institute Report. www.epi.org/publications/entry/ib223/.

Brown, Wendy. 2006. "American nightmare: Neoliberalism, neoconservatism, and de-democratization." Political Theory 34: 690-714.

CNN Money. 2007. "Wal-Mart CEO excited about holidays." 24 October 2007. http://money.cnn .com/2007/10/24/news/companies/lee_scott/ ?postversoin $=2007102417$.

Cohen, Lizabeth. 2003. A consumer's republic: The politics of mass consumption in post-war America. New York: Random House.

Collins, Jane. 2010. "The age of Wal-Mart." In The insecure American: How we got here and what we should do about it, ed. by Hugh Gusterson and
Catherine Besteman, 97-112. Berkeley and Los Angeles: University of California Press.

Dube, Arindrajit, and Kenneth Jacobs. 2004. Hidden cost of Wal-Mart jobs: Use of safety net programs by Wal-Mart workers in California. University of California at Berkeley Labor Center. http:// laborcenter.berkeley.edu/retail/walmart.pdf.

Economic Policy Institute. 2010. "Prolonged economic downturn pushes more people into poverty." 23 September, news report, http:// www.epi.org/publications/entry/ib223/

Featherstone, Liza. 2004. Selling women short: The landmark battle for workers' rights at Wal-Mart. New York: Basic Books.

- 2005. "Down and out in discount America." The Nation, January 3. http://www.thenation .com/article/down-and-out-discount-america.

Fishman, Charles. 2006. The Wal-Mart effect. New York: Penguin.

Galbraith, John Kenneth. [1952] 1993. American capitalism: The concept of countervailing power. New Brunswick, N.J.: Transaction Books.

Gereffi, Gary. 2004. "Interview: Is Wal-Mart Good for America?" "Frontline," 9 September 2004. www.pbs.org/wgbh/pages/frontline/shows/ walmart/interviews/gereffi.html

Gereffi, Gary, and Michelle Christian. 2009. "The impacts of Wal-Mart: The rise and consequences of the world's dominant retailer." Annual Review of Sociology 35: 573-91.

Goetz, S., and H. Swaminathan. 2006. "Wal-Mart and county-wide poverty." Social Science Quarterly 87 (2): 211-26.

Gramsci, Antonio. [1937] 1971. Selections from the prison notebooks. New York: International Publishers.

Greenwald, Robert. 2005. Wal-Mart: The high cost of low price. New York: Brave New Films.

Huffington Post. 2010. "Wal-Mart plans to hire $500 \mathrm{~K}$ in the next five years." 4 June 2010.

Irwin, Elena G., and Jill Clark. 2006. "Wall Street vs. Main Street: What are the benefits and costs of Wal-Mart to local communities?" Choices: A Publication of the American Agricultural Economics Association 21 (2): 117-22.

Lichtenstein, Nelson. 2004. "Interview: Is Wal-Mart good for America?" "Frontline," 16 November 16, 2004. www.pbs.org/wgbh/pages/frontline/ shows/walmart/interviews/lichtenstein.html.

. 2009. The retail revolution: How Wal-Mart created a brave new world of business. New York: Metropolitan Books. 
Lichtenstein, Nelson, ed. 2006. Wal-Mart: The face of twenty-first century capitalism. New York: New Press.

Moreton, Bethany E. 2009. To serve God and WalMart: The making of Christian free enterprise. Cambridge, Mass.: Harvard University Press.

New York Times. 2010a. "Wal-Mart posts slower growth as luxury and home goods rebound." 19 May.

_.2010b. "With a backdrop of glitz, Wal-Mart stresses its global growth." 5 June.

- 2010c. "In Wal-Mart and Home Depot results, a worried consumer." 17 August.

Newsweek. 2009. "Watching us save, one cart at a time." 2 May 2009. http://www.newsweek.com/ 2009/05/01/watching-us-save-one-cart-at-atime.html (accessed 17 May 2011).

Reuters. 2010. "Wal-Mart prices on the rise: J. P. Morgan study." 10 August.

Strasser, Susan. 1989. Satisfaction guaranteed: The making of the American mass market. Washington: Smithsonian Institution Press.

Tilly, Christoper. 2007. "Wal-Mart and its workers:
NOT the same all over the world." Connecticut Law Review 39 (4): 1805-23.

Time. 2010. "Has Wal-Mart's price chopping come to an end?" 5 October.

Veblen, Thorstein. 1899. Theory of the leisure class. New York: Macmillan.

Wall Street Journal. 2010. "These families shop when aid arrives." 2 October. http://online.wsj .com/article/SB1000142405274870402930457552 6120920214834.html.

Wal-Mart Corporate. 2011. About Us. http://wal martstores.com/AboutUs/8123.aspx. (Accessed May 17, 2011).

Walmartwatch.com. 2010. http://walmartwatch.org/ blog/archives/category/working-at-walmart/ wages/ (Accessed November 11, 2010).

Webb, Sheila. 2006. "The tale of advancement: Life magazine's construction of the modern American success story." Journalism History 32 (1): 2-12.

Zukin, Sharon. 2004. Point of purchase: How shopping changed American culture. New York: Routledge. 